\title{
Real-world effectiveness of amlodipine/valsartan and amlodipine/valsartan/hydrochlorothiazide in high-risk patients and other subgroups
}

This article was published in the following Dove Press journal:

Vascular Health and Risk Management

21 January 2015

Number of times this article has been viewed

\author{
Samir Helmy Assaad-Khalil' \\ Robert Najem² \\ Jorge Sison ${ }^{3}$ \\ Asad Riaz Kitchlew ${ }^{4}$ \\ Belong $\mathrm{Cho}^{5}$ \\ Kwo-Chang Ueng 6 \\ Shelley DiTommaso ${ }^{7}$ \\ Abhijit Shete ${ }^{7}$ \\ 'Department of Diabetology, \\ Lipidology and Metabolism, \\ Alexandria Faculty of Medicine, \\ Alexandria University, Alexandria, \\ Egypt; ${ }^{2}$ Lebanese University Hospital, \\ Beirut, Lebanon; ${ }^{3}$ Medical Center \\ Manila, Manila, Philippines; ${ }^{4}$ Pakistan \\ Institute of Medical Sciences, \\ Islamabad, Pakistan; ${ }^{5}$ Seoul National \\ University College of Medicine, Seoul, \\ South Korea; ${ }^{6}$ Chung Shan Medical \\ University Hospital, Taichung City, \\ Taiwan; ${ }^{7}$ Novartis Pharma AG, Basel, \\ Switzerland
}

Background: The clinical EXCITE (EXperienCe of amlodIpine and valsarTan in hypErtension) study reported clinically relevant blood pressure (BP) reductions across all doses of amlodipine/valsartan (Aml/Val) and Aml/Val/hydrochlorothiazide (HCT) single-pill combinations. The study prospectively observed a multiethnic population of hypertensive patients for 26 weeks who were treated according to routine clinical practice. Here, we present the results in high-risk subgroups including the elderly, obese patients, and patients with diabetes or isolated systolic hypertension. In addition, we present a post hoc analysis as per prior antihypertensive monotherapy and dual therapy.

Methods: Patients prescribed Aml/Val or Aml/Val/HCT were assessed in this $26 \pm 8$ week, noninterventional, multicenter study across 13 countries in the Middle East and Asia. Changes in mean sitting systolic BP, mean sitting diastolic BP, and overall safety were assessed.

Results: Of a total of 9,794 patients analyzed, 8,603 and 1,191 patients were prescribed Aml/Val and $\mathrm{Aml} / \mathrm{Val} / \mathrm{HCT}$, respectively. Among these, $15.5 \%$ were elderly, $32.5 \%$ were obese, $31.3 \%$ had diabetes, and $9.8 \%$ had isolated systolic hypertension. Both Aml/Val and Aml/Val/HCT single-pill combinations, respectively, were associated with clinically relevant and significant mean sitting systolic/diastolic BP reductions across all subgroups: elderly patients $(-32.2 /-14.3 \mathrm{mmHg}$ and $-38.5 /-16.5 \mathrm{mmHg})$, obese patients $(-32.2 /-17.9 \mathrm{mmHg}$ and $-38.5 /-18.4 \mathrm{mmHg})$, diabetic patients $(-30.3 /-16.1 \mathrm{mmHg}$ and $-34.4 /-16.6 \mathrm{mmHg})$, and patients with isolated systolic hypertension $(-25.5 /-4.1 \mathrm{mmHg}$ and $-30.2 /-5.9 \mathrm{mmHg}$ ). Incremental BP reductions with $\mathrm{Aml} / \mathrm{Val}$ or Aml/Val/HCT single-pill combinations were also observed in patients receiving prior monotherapy or dual therapy for hypertension. Overall, both Aml/Val and Aml/Val/HCT were generally well tolerated.

Conclusion: This large, multiethnic study supports the evidence that Aml/Val and Aml/Val/ HCT single-pill combinations are effective in diverse and clinically important subgroups of patients with hypertension.

Keywords: amlodipine, hydrochlorothiazide, single-pill combinations, real world, valsartan

\section{Introduction}

Hypertension, a major modifiable risk factor for cardiovascular disease, is estimated to affect 639 million adults in economically developing regions (classification as per the World Bank's 1993 World Development Report). ${ }^{1}$ An $80 \%$ rise in hypertension is predicted by 2025 , with an estimated three quarters of patients ( 1.15 billion) worldwide residing in developing countries. ${ }^{1}$

Despite the availability of effective antihypertensive agents, hypertension remains poorly controlled in the majority of patients. ${ }^{2}$ In many patients, the presence of multiple risk factors (advanced age, obesity) or concomitant target organ damage
Correspondence: Samir Helmy Assaad-Khalil

Department of Diabetology, Lipidology and Metabolism,Alexandria Faculty of Medicine,Alexandria University, Champollion Street, Alexandria, 21526 , Egypt

Tel +201222197789

Fax +20 334874204

Email assaadkhalil@hotmail.com 
(eg, diabetes mellitus, increased pulse pressure) place these patients at heightened risk of cardiovascular events. ${ }^{3,4}$ In this regard, the management of hypertension is particularly important in elderly, obese, and diabetic patients as well as patients with isolated systolic hypertension (ISH)..$^{5-7}$ Many of these patients may benefit from combination therapy $^{8-10}$ to achieve adequate blood pressure (BP) control. ${ }^{11}$ Recommended effective combination therapies include renin-angiotensin-aldosterone system blockers such as angiotensin receptor blockers or angiotensin-converting enzyme inhibitors administered together with calcium channel blockers and/or diuretics. ${ }^{12-14}$

The clinical EXCITE (EXperienCe of amlodIpine and valsarTan in hypErtension) study evaluated the effectiveness and safety of amlodipine/valsartan $(\mathrm{Aml} / \mathrm{Val})$ and amlodipine/valsartan/hydrochlorothiazide (Aml/Val/HCT) single-pill combinations (SPCs) over a period of $26 \pm 8$ weeks in patients with hypertension in a real-world setting in the Middle East and Asia. ${ }^{15}$ Here, we discuss the findings from the EXCITE study in subgroups of patients categorized as high-risk, including the elderly, the obese, and those with ISH or diabetes (considering that the mean age group of the EXCITE population is over 50 years, we believe that the diabetes patients in EXCITE study are predominantly patients with type 2 diabetes mellitus and we refer to this group as "diabetes" throughout this paper). In addition, we also report findings from a post hoc analysis (in patients who were prescribed Aml/Val or Aml/Val/HCT SPCs by the treating physician as a part of their routine clinical practice) assessing changes in BP as per prior antihypertensive monotherapy and dual therapy from the overall study.

\section{Materials and methods}

\section{Study design and patients}

EXCITE was a prospective, multinational, multicenter study conducted in countries in the Middle East (Bahrain, Egypt, Kuwait, Lebanon, Oman, Qatar, and United Arab Emirates) and Asia (Indonesia, Hong Kong, Pakistan, Philippines, South Korea, and Taiwan) between June 2010 and November 2012. It was conducted as a noninterventional study, in accordance with the definition from the European Medicines Agency (Directive 2001/20/EC). The study design and overall results have been described in detail elsewhere. ${ }^{15}$

The study included patients aged $\geq 18$ years with an established diagnosis of hypertension, who were prescribed Aml/ Val or Aml/Val/HCT SPCs by the treating physician as a part of their routine clinical practice, and who provided written informed consent. The following drug dosages (prescribed in accordance with local prescribing information) were studied: $\mathrm{Aml} / \mathrm{Val}$ at $5 / 80 \mathrm{mg}, 5 / 160 \mathrm{mg}, 10 / 160 \mathrm{mg}, 5 / 320 \mathrm{mg}$, or $10 / 320 \mathrm{mg}$, and $\mathrm{Aml} / \mathrm{Val} / \mathrm{HCT}$ at $5 / 160 / 12.5 \mathrm{mg}, 10 / 160 / 12.5$ $\mathrm{mg}, 5 / 160 / 25 \mathrm{mg}, 10 / 160 / 25 \mathrm{mg}$, or 10/320/25 mg. Patients with any contraindication to treatments as per the local prescribing information were excluded from participation. The observational period of $26 \pm 8$ weeks included data from at least two routine examinations for each patient at baseline, week 13 (optional), and study endpoint (26 \pm 8 weeks).

\section{Endpoints}

Effectiveness was assessed as the change from baseline to final visit (at 26 \pm 8 weeks) in mean sitting systolic BP and mean sitting diastolic BP in defined subgroups: elderly ( $\geq 65$ years of age), obese (body mass index $\geq 30 \mathrm{~kg} / \mathrm{m}^{2}$ ), patients with diabetes, and patients with ISH (mean sitting systolic BP $\geq 140 \mathrm{mmHg}$ and mean sitting diastolic $\mathrm{BP}<90 \mathrm{mmHg}$ ).

In addition, mean reductions in mean sitting systolic/ diastolic BP from baseline to end of study were reported according to antihypertensive therapy classes received prior to $\mathrm{Aml} / \mathrm{Val}$ or $\mathrm{Aml} / \mathrm{Val} / \mathrm{HCT}$ prescription. Prior antihypertensives included angiotensin receptor blockers, angiotensinconverting enzyme inhibitors, calcium channel blockers, beta-blockers, or diuretics as monotherapy or dual combinations of an angiotensin receptor blocker or angiotensinconverting enzyme inhibitor with a calcium channel blocker or diuretics and beta-blockers with diuretics.

Safety, according to reported adverse events and serious adverse events, was evaluated for the overall EXCITE study population ${ }^{15}$ and is not reported for the subgroups of highrisk patients or for the subgroups included in the post hoc analysis by prior antihypertensive treatment.

\section{Statistical analysis}

Data from one umbrella protocol from 13 countries (Bahrain, Egypt, Hong Kong, Indonesia, Kuwait, Lebanon, Oman, Pakistan, Philippines, Qatar, South Korea, Taiwan, and United Arab Emirates) were pooled for analysis in this report. Patients from Saudi Arabia were excluded from this analysis due to noncompliance with the study protocol. ${ }^{15}$

Effectiveness and safety analyses were performed on the full analysis set, consisting of all patients who provided informed consent and entered the study. ${ }^{15}$ A paired sample $t$-test was used to analyze the change in BP from baseline to the end of the study in the study groups. Mean data are presented with $95 \%$ confidence intervals. Last observation carried forward was used as the imputation method for patients who discontinued before completion of the study. 
The incidence of adverse events and serious adverse events was summarized with frequency counts and percentages. The statistical analysis was performed using SAS version 9.2 (SAS Institute, Cary, NC, USA).

\section{Results}

\section{Patients}

The number of patients per subgroup and by prior antihypertensive treatment are presented in Table 1. Patient disposition, demographics, and baseline characteristics of the total study population are described elsewhere. ${ }^{15}$ Briefly stated, in the overall study, 8,603 patients received Aml/Val and 1,191 patients received $\mathrm{Aml} / \mathrm{Val} / \mathrm{HCT}$. The mean age of the patients overall was $53.2 \pm 11.35$ years, $60.6 \%$ were male, $47.2 \%$ were Caucasian, $41.4 \%$ were Asian, and the mean duration of hypertension was $5.9 \pm 6.5$ years.

\section{$B P$ reductions from baseline to endpoint} Aml/Val (Figure 1) and Aml/Val/HCT (Figure 2) SPCs were associated with significant BP reductions from baseline to end of study (26 \pm 8 weeks) in the subgroups, including the elderly (mean sitting systolic/diastolic BP on Aml/Val, -32.2/-14.3 $\mathrm{mmHg}$ and $\mathrm{Aml} / \mathrm{Val} / \mathrm{HCT},-38.5 /-16.5 \mathrm{mmHg}$ ), patients with obesity (Aml/Val, -32.2/-17.9 $\mathrm{mmHg}$ and $\mathrm{Aml} / \mathrm{Val} / \mathrm{HCT},-38.5 /-18.4 \mathrm{mmHg}$ ), and patients with diabetes (Aml/Val, -30.3/-16.1 $\mathrm{mmHg}$ and Aml/Val/ HCT, $-34.4 /-16.6 \mathrm{mmHg})$. In patients with ISH, the reduction obtained was $-25.5 /-4.1 \mathrm{mmHg}$ with $\mathrm{Aml} / \mathrm{Val}$ and $-30.2 /-5.9 \mathrm{mmHg}$ with $\mathrm{Aml} / \mathrm{Val} / \mathrm{HCT}$. The reductions

Table I Summary of patient subgroups

\begin{tabular}{|c|c|c|}
\hline Subgroup & $\begin{array}{l}\text { Aml/Val } \\
n=8,603 \\
n(\%)\end{array}$ & $\begin{array}{l}\text { Aml/Val/HCT } \\
n=I,|9| \\
n(\%)\end{array}$ \\
\hline Elderly ( $\geq 65$ years) & $1,239(14.4)$ & $280(23.5)$ \\
\hline Obese patients $\left(\mathrm{BMI} \geq 30 \mathrm{~kg} / \mathrm{m}^{2}\right)$ & $2,766(32.2)$ & $418(35.1)$ \\
\hline Diabetic & $2,663(31.0)$ & $400(33.6)$ \\
\hline $\begin{array}{l}\mathrm{ISH}(\mathrm{msSBP} \geq 140 \mathrm{mmHg} \\
\text { and } \mathrm{msDBP}<90 \mathrm{mmHg})\end{array}$ & $838(9.7)$ & $117(9.8)$ \\
\hline $\begin{array}{l}\text { Prior antihypertensive } \\
\text { monotherapy* }\end{array}$ & $2,575(29.9)$ & - \\
\hline $\begin{array}{l}\text { Prior antihypertensive } \\
\text { dual therapy* }\end{array}$ & - & 235 (19.7) \\
\hline \multicolumn{3}{|c|}{$\begin{array}{l}\text { Notes: *Post-hoc analysis in patients receiving prior monotherapy and dual } \\
\text { combination therapy, respectively, in the } A m \mathrm{l} / \mathrm{Val} \text { and } \mathrm{Aml} / \mathrm{Val} / \mathrm{HCT} \text { groups. Patients } \\
\text { receiving prior monotherapy in the } \mathrm{Aml} / \mathrm{Val} / \mathrm{HCT} \text { group and dual combination } \\
\text { therapy in the } \mathrm{Aml} / \mathrm{Val} \text { group were not studied. } \\
\text { Abbreviations: Aml/Val, amlodipine/valsartan; Aml } / \mathrm{Val} / \mathrm{HCT} \text {, amlodipine/ } \\
\text { valsartan/hydrochlorothiazide; } \mathrm{BMl} \text {, body mass index; } \mathrm{SH} \text {, isolated systolic } \\
\text { hypertension; msDBP, mean sitting diastolic blood pressure; msSBP, mean sitting } \\
\text { systolic blood pressure. }\end{array}$} \\
\hline
\end{tabular}

were generally consistent with those observed in the total study population. ${ }^{15}$

In patients receiving prior monotherapy, $\mathrm{Aml} / \mathrm{Val}$ SPC (Figure 3) provided incremental mean BP reductions (mean sitting systolic/diastolic BP on Aml/Val, overall $-29.9 /-16.2 \mathrm{mmHg}$ ) at the end of the study. Similar results were observed with Aml/Val/HCT SPC (Figure 4) in patients receiving prior dual therapy (mean sitting systolic/ diastolic BP on Aml/Val, [overall, -32.7/-15.3 mmHg]). The reductions obtained with the various doses of Aml/Val SPCs or Aml/Val/HCT SPCs were broadly similar across various monotherapy classes or dual combination therapy.

\section{Safety}

The safety and tolerability of Aml/Val and Aml/Val/HCT SPCs in the overall patient population is published elsewhere ${ }^{15}$ and summarized here. Safety was not separately analyzed in the patient subgroups reported here. In the overall study, adverse events were reported in $963(11.2 \%)$ patients in the Aml/Val group and in $73(6.1 \%)$ patients in the $\mathrm{Aml} / \mathrm{Val} / \mathrm{HCT}$ group. The most frequently reported adverse events with Aml/Val and $\mathrm{Aml} / \mathrm{Val} / \mathrm{HCT}$ were edema (2.0\% and $3.3 \%$, respectively), peripheral edema $(1.2 \%$ and $0.8 \%)$, headache $(1.0 \%$ and $0.2 \%)$, and cough $(0.6 \%$ and $0.3 \%)$. The incidence of serious adverse events was low and reported by $50(0.5 \%)$ patients (Aml/Val, 49 [0.6\%]; Aml/Val/HCT, one [0.1\%]). Cardiac disorders were the most frequent serious adverse events, reported only in the Aml/Val group (23 [0.3\%] patients). Thirteen deaths were reported, none of which were considered by the investigators to be related to the medication of interest. ${ }^{15}$

\section{Discussion}

The EXCITE study was conducted in a large, multiethnic, hypertensive population treated as per routine clinical practice and reported clinically meaningful BP reductions across all doses of Aml/Val and Aml/Val/HCT SPCs over 26 weeks. ${ }^{15}$ In this analysis of important subgroups from the EXCITE study, including the elderly, obese patients, and patients with diabetes or ISH, significant and clinically relevant BP reductions with $\mathrm{Aml} / \mathrm{Val}$ and $\mathrm{Aml} / \mathrm{Val} / \mathrm{HCT} \mathrm{SPC}$ s were observed and were broadly similar to those reported in the overall population. ${ }^{15}$ The importance of appropriately treating these hypertensive patient subtypes deserves due consideration. Diabetes is an independent risk factor for cardiovascular disease, with an odds ratio of $2-4$ for cardiovascular mortality compared with patients with no diabetes and a greater risk of death in women than in men. ${ }^{16}$ The coexistence of diabetes and hypertension is also noteworthy; by 45 years 


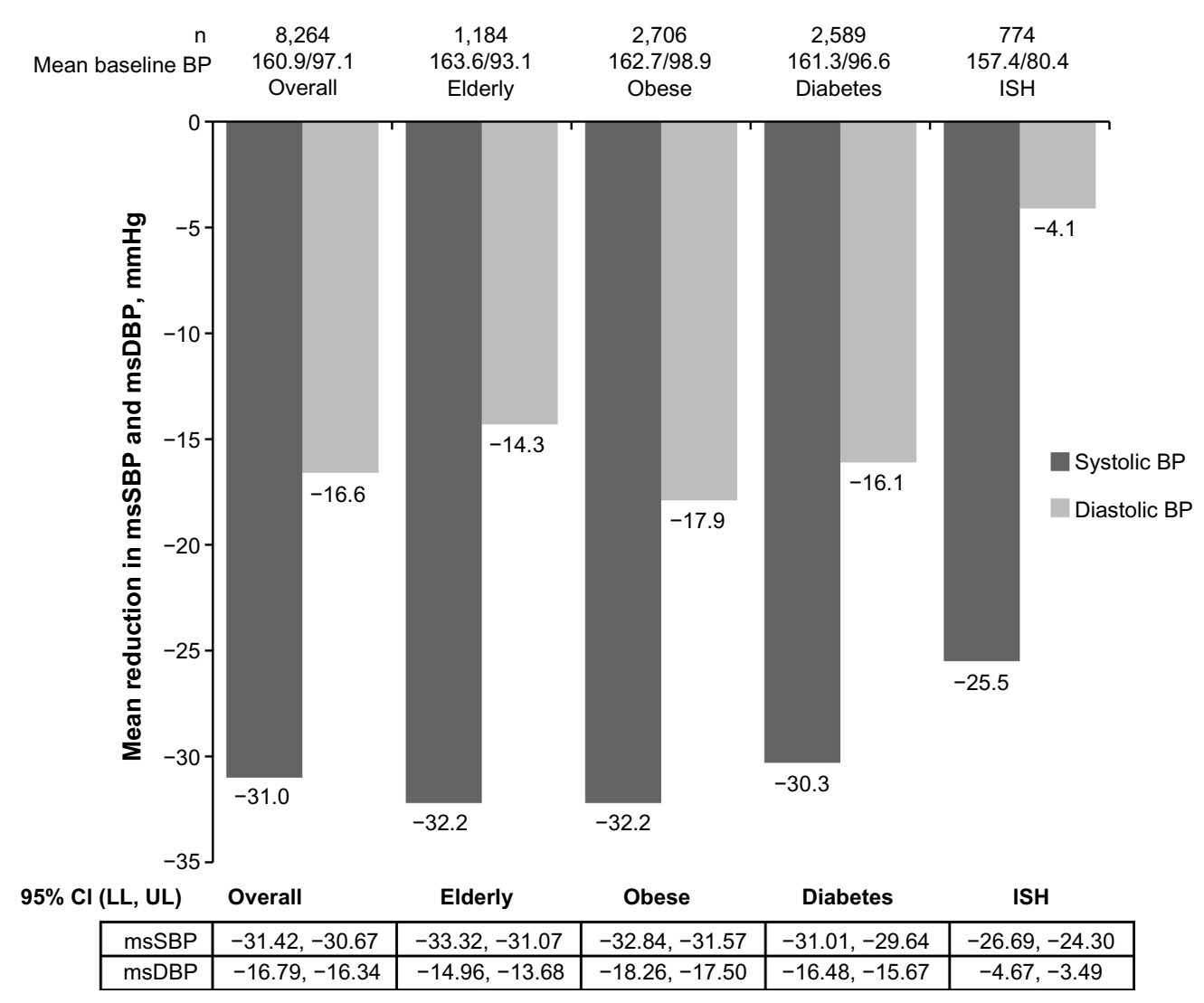

Figure I Mean reductions in msSBP and msDBP at $26 \pm 8$ weeks in subgroups treated with $\mathrm{Aml} / \mathrm{Val}$.

Note: Overall group includes 8,603 patients who received $\mathrm{Aml} / \mathrm{Val}$, subgroups were defined as elderly ( $\geq 65$ years of age), obesity (BMl $\geq 30 \mathrm{~kg} / \mathrm{m}^{2}$ ), and ISH (msSBP $\geq 140 \mathrm{mmHg}$ and $\mathrm{msDBP}<90 \mathrm{mmHg}$ ).

Abbreviations: Aml/Val, amlodipine/valsartan; BMI, body mass index; BP, blood pressure; Cl, confidence interval; ISH, isolated systolic hypertension; LL, lower limit; msDBP, mean sitting diastolic blood pressure; msSBP, mean sitting systolic blood pressure; UL, upper limit.

of age, approximately $40 \%$ of persons with type 2 diabetes have hypertension, increasing to $60 \%$ in patients aged 75 years; these highly comorbid conditions together further compound cardiovascular risk in such patients. ${ }^{17}$ Many international guidelines have until recently recommended aggressive management of hypertension to lower BP targets in these individuals. ${ }^{4}$

The association between obesity and high BP is well documented, with estimates suggesting that a $10 \%$ increase in body weight may be associated with systolic BP increases of up to $6.5 \mathrm{mmHg} .{ }^{18}$ Furthermore, the coexistence of hypertension with obesity may have an additive effect in increasing cardiovascular risk and complications and is associated with poor control of hypertension. ${ }^{19}$

The management of hypertension in the elderly is indeed a challenge; high BP can occur in more than two thirds of individuals after the age of 65 years; and the elderly are known to be a population with low rates of BP control. ${ }^{20}$ Clinical trials conducted exclusively in the elderly are limited, leading to disparity in the recommendations for optimal BP control offered by various committees/socieites. ${ }^{4,21}$ ISH is also commonly observed in this group of patients; these agerelated changes in BP are manifestations of a generalized process of increasing arterial stiffness that is a consequence of progressive replacement of elastin by collagen in the walls of large arteries. ISH is an important risk factor for excess cardiovascular mortality, is highly prevalent in the elderly, and is a precursor to heart failure in this population. ${ }^{22}$

In our analysis, $\mathrm{Aml} / \mathrm{Val}$ and $\mathrm{Aml} / \mathrm{Val} / \mathrm{HCT}$ SPCs consistently provided mean systolic BP reductions of $25-32 \mathrm{mmHg}$ in addition to meaningful reductions in mean diastolic BP in each of these subgroups. These results are reassuring, as previously conducted randomized clinical trials using $\mathrm{Aml} / \mathrm{Val}$ or Aml/Val/HCT combinations have also reported significant BP-lowering efficacy and tolerability regardless of age, ${ }^{23-26}$ race, ${ }^{23,24,27}$ or sex,,$^{23}$ across hypertension severities, ${ }^{24,26,28}$ in the presence of obesity, ${ }^{23,26}$ in patients with moderate to severe (stage 2) hypertension, ${ }^{25,27,29}$ and in those with diabetes. ${ }^{26}$ Likewise, several observational studies of Aml/Val conducted in the People's Republic of China, Turkey, and Germany have reported effective BP reductions/control with good tolerability in various subgroups studied. ${ }^{30-32}$ 


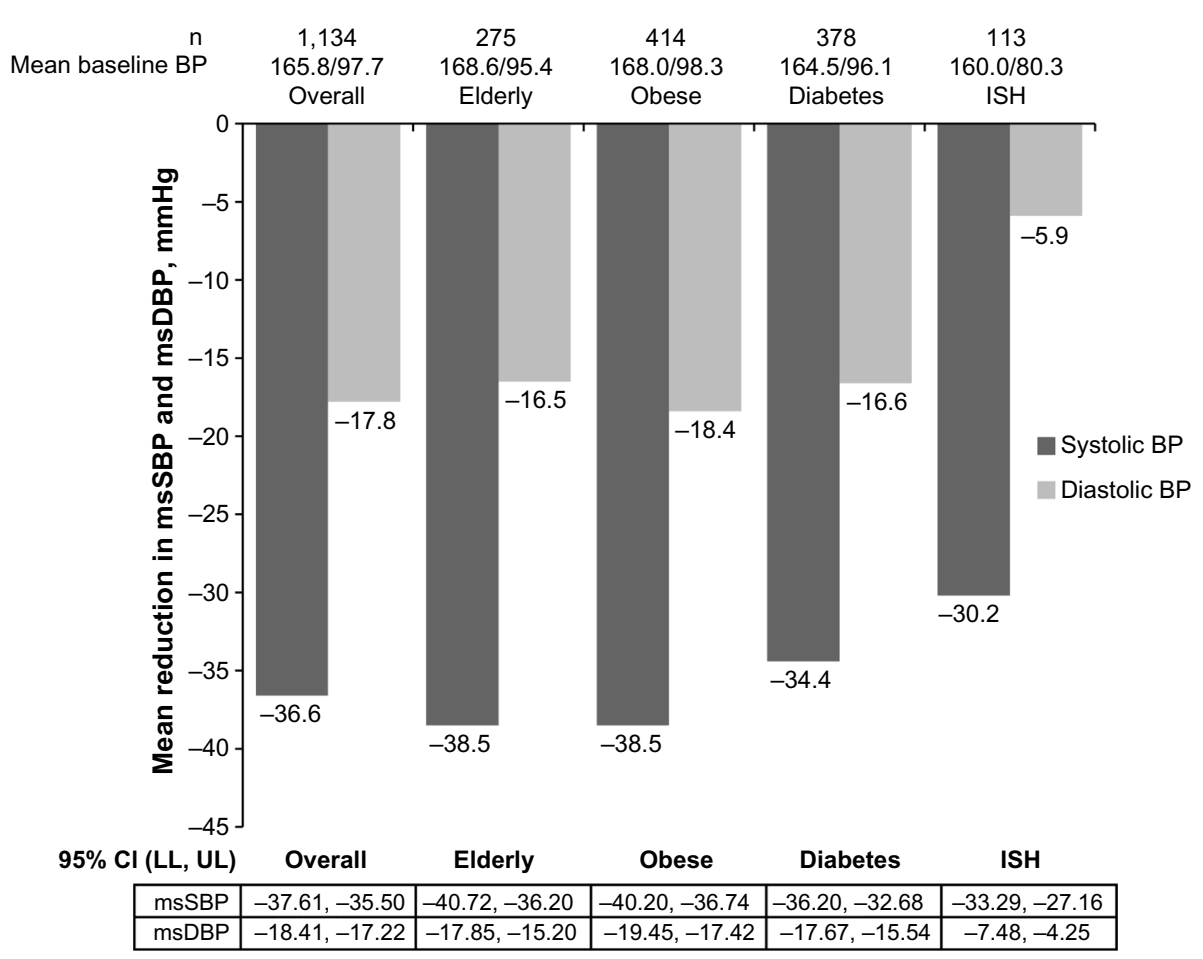

Figure 2 Mean reductions in $\mathrm{msSBP}$ and $\mathrm{msDBP}$ at $26 \pm 8$ weeks in subgroups treated with $\mathrm{Aml} / \mathrm{Val} / \mathrm{HCT}$.

Note: Overall group includes 8,603 patients who received $\mathrm{Aml} / \mathrm{Val}$, subgroups were defined as elderly ( $\geq 65$ years of age), obesity (BMI $\geq 30 \mathrm{~kg} / \mathrm{m}^{2}$ ), and ISH (msSBP $\geq 140 \mathrm{mmHg}$ and $\mathrm{msDBP}<90 \mathrm{mmHg}$ ).

Abbreviations: Aml/Val, amlodipine/valsartan; Aml/Val/HCT, amlodipine/valsartan/hydrochlorothiazide; BMl, body mass index; BP, blood pressure; Cl, confidence interval; $\mathrm{ISH}$, isolated systolic hypertension; LL, lower limit; msDBP, mean sitting diastolic blood pressure; msSBP, mean sitting systolic blood pressure; UL, upper limit.

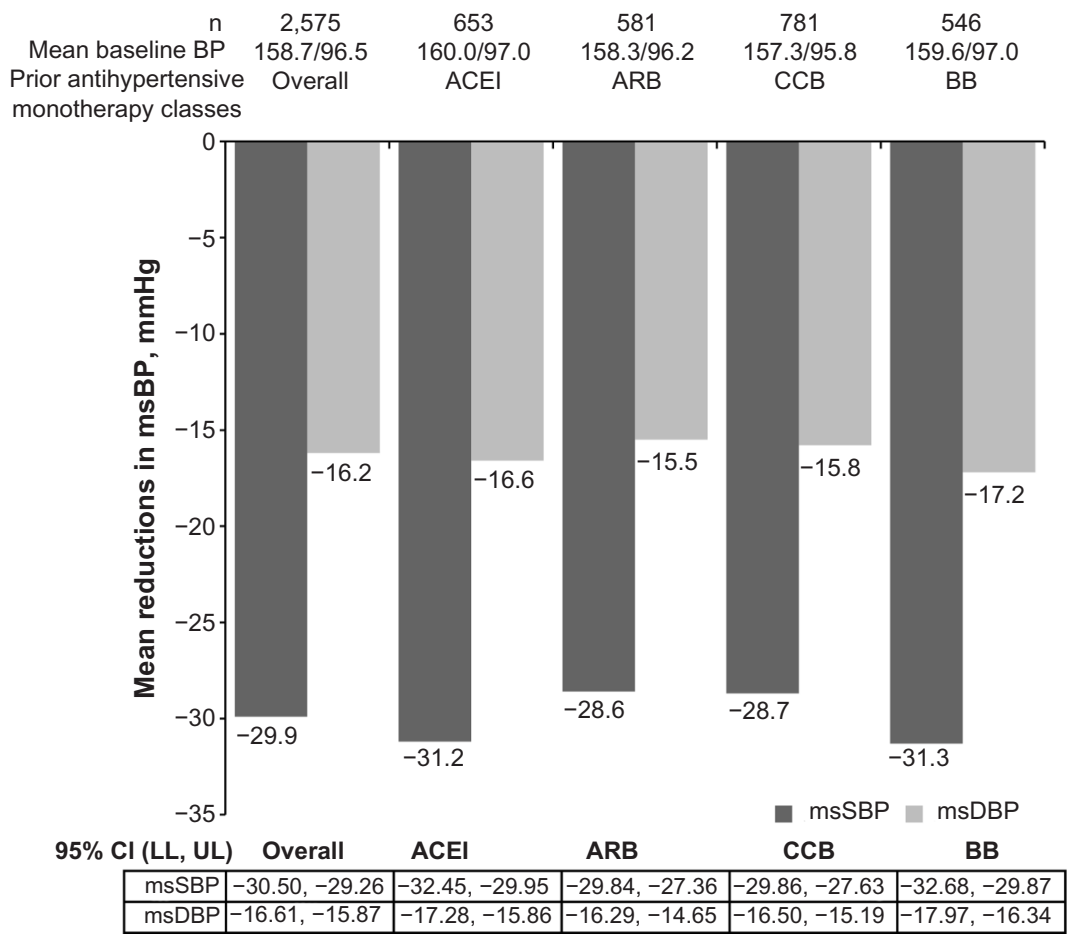

Figure 3 Mean reductions in $\mathrm{msSBP}$ and $\mathrm{msDBP}$ with $\mathrm{Aml} / \mathrm{Val}$ combination by prior antihypertensive monotherapy class.

Notes: Post hoc analysis. Baseline was defined as prior to start of Aml/Val. The end of the study defined as week 26 . Patients who did not take any antihypertensive medication during the observational period, in addition to $\mathrm{Aml} / \mathrm{Val}$, and did not switch to $\mathrm{Aml} / \mathrm{Val} / \mathrm{HCT}$ were only included. In addition, patients who did not receive additional treatment prior to study entry were included. Only 14 patients received prior diuretic monotherapy and the mean reduction in BP was $-30.7 /-19.3 \mathrm{mmHg}$ from baseline $(162.9 / 102.9 \mathrm{mmHg})$ to endpoint.

Abbreviations: ACEl, angiotensin-converting enzyme inhibitor; Aml/Val, amlodipine/valsartan; Aml/Val/HCT, amlodipine/valsartan/hydrochlorothiazide; ARB, angiotensin receptor blocker; $\mathrm{BB}$, beta-blocker; $\mathrm{BP}$, blood pressure; $\mathrm{CCB}$, calcium channel blocker; $\mathrm{Cl}$, confidence interval; LL, lower limit; msBP, mean sitting blood pressure; msDBP, mean sitting diastolic blood pressure; msSBP, mean sitting systolic blood pressure; UL, upper limit. 


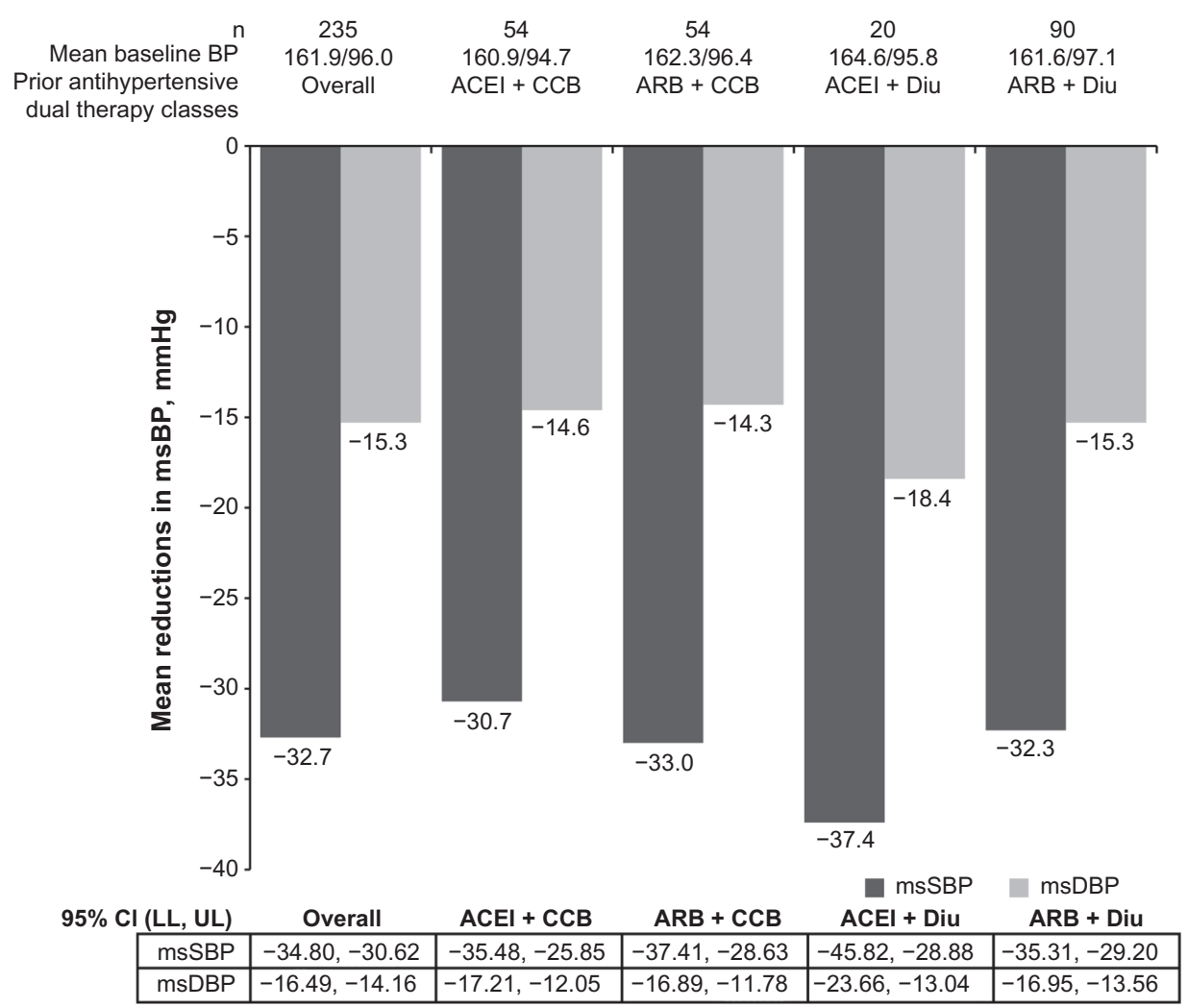

Figure 4 Mean reductions in msSBP and msDBP with $\mathrm{Aml} / \mathrm{Val} / \mathrm{HCT}$ combination by prior antihypertensive dual therapy classes.

Notes: Post hoc analysis. Baseline was defined as prior to start of Aml/Val/HCT. End of the study defined as week 26 . Patients who did not take any antihypertensive medication during the observational period, in addition to $\mathrm{Aml} / \mathrm{Val} / \mathrm{HCT}$, and did not switch to $\mathrm{Aml} / \mathrm{Val}$ were only included. In addition, patients who did not receive additional treatment prior to study entry were only included. Only 17 patients received BBs and diuretic combinations and the mean reduction in BP was $-35.2 /-17.5 \mathrm{mmHg}$ from baseline (161.6/93.7 mmHg).

Abbreviations: ACEl, angiotensin-converting enzyme inhibitor; Aml/Val, amlodipine/valsartan; Aml/Val/HCT, amlodipine/valsartan/hydrochlorothiazide; ARB, angiotensin receptor blocker; BBs, beta-blockers; BP, blood pressure; CCB, calcium channel blocker; Cl, confidence interval; Diu, diuretic; LL, lower limit; msBP, mean sitting blood pressure; msDBP, mean sitting diastolic blood pressure; msSBP, mean sitting systolic blood pressure; UL, upper limit.

Major hypertension studies have shown that many patients with hypertension will require two or more antihypertensive drugs to achieve their BP goals, and addition of a further BP-lowering therapy (particularly from another therapeutic class) to an existing antihypertensive drug regimen is likely to deliver additional BP lowering and improved BP control. ${ }^{4}$ In our analysis, both Aml/Val (dual SPC) and Aml/Val/HCT (triple SPC) provided incremental BP reductions in patients receiving prior monotherapy or dual therapy, respectively. In addition, the reductions were consistent across different classes of prior antihypertensive monotherapy and dual combinations. The results observed were not dissimilar to those reported in previously conducted randomized clinical trials, such as the 16-week EX-FAST study where the Aml/Val combination delivered meaningful BP reductions in patients uncontrolled on antihypertensive monotherapy, including beta-blockers, calcium channel blockers, angiotensin receptor blockers, angiotensin-converting enzyme inhibitors, and diuretics. ${ }^{26}$ Our findings of BP reductions with an Aml/Val
SPC in patients previously treated with monotherapy are also similar to those reported in another large observational study in a real-life setting and conducted in Chinese patients. ${ }^{32}$ Similarly, the incremental reductions observed with the triple SPC in patients previously receiving dual combinations are meaningful and reinforce the clinical utility of having a triple combination therapy in the armamentarium of a treating physician, particularly in view of the observation that up to one third of hypertensive patients are likely to require more than two agents to achieve BP control. ${ }^{33}$

This analysis of the EXCITE study further supports the efficacy of Aml/Val and Aml/Val/HCT SPCs in high-risk patients and in patients not adequately benefiting from prior monotherapy or dual therapy. The limitations of this analysis include the absence of a separate safety assessment for each subgroup and the post hoc nature of analysis for the prior antihypertensive monotherapy and dual therapy groups. However, the observational nature of the study has enabled collection of real-world data from a more naturalistic clinical setting and 
from a large number of patients. Notably, useful data have been collected for a number of countries in the Middle East and Asia, where research on antihypertensive treatment has been limited. The large number of patients included also serves to increase the validity of the data, as indicated by the narrow confidence intervals for the main study outcomes.

\section{Conclusion}

In the large multiethnic EXCITE study, conducted in a real-world setting, Aml/Val and Aml/Val/HCT SPCs were effective in high-risk patients with hypertension, including the elderly, and patients with obesity, diabetes, or ISH. Incremental BP reductions were also seen in a post hoc analysis for patients treated with prior antihypertensive monotherapy or dual therapy.

\section{Acknowledgments}

The study was funded by Novartis Pharma AG, Basel, Switzerland. The authors thank all clinical investigators and study coordinators at the participating centers and all patients who participated in the study. The authors would like to acknowledge Sashka Hristoskova and Ditte Knap from Novartis Pharma AG, Basel, Switzerland, and Dr Mahomed Kadwa from Novartis South Africa (Pty) Ltd, South Africa, for providing suggestions regarding the content of the manuscript. The authors would like to thank Sreedevi Boggarapu of Novartis Healthcare Pvt Ltd for developing the first draft of the manuscript that was prepared under the guidance of the lead author. The authors also acknowledge the contributions of Madhavi Dokku (Novartis Healthcare Pvt Ltd) and Kanaka Sridharan (Novartis Pharmaceuticals Corporation, East Hanover, NJ, USA) for providing valuable feedback and review during development of the manuscript.

\section{Disclosure}

SHA-K, RN, JS, ARK, BC, and K-CU have received investigator fees related to the conduct of the EXCITE study from Novartis and its affiliates. SD is an employee of Novartis Pharma AG. AS is an employee and shareholder of Novartis Pharma AG. The authors report no other conflicts of interest in this work.

\section{References}

1. Kearney PM, Whelton M, Reynolds K, Muntner P, Whelton PK, He J. Global burden of hypertension: analysis of worldwide data. Lancet. 2005;365:217-223.

2. Chow CK, Teo KK, Rangarajan S, et al. Prevalence, awareness, treatment, and control of hypertension in rural and urban communities in high-, middle-, and low-income countries. JAMA. 2013;310: 959-968.

3. Gradman AH. Managing high-risk patients with hypertension: focus on the renin-angiotensin system. J Clin Hypertens (Greenwich). 2004;6: 501-508.
4. Mancia G, Fagard R, Narkiewicz K, et al. 2013 ESH/ESC Guidelines for the management of arterial hypertension: the Task Force for the management of arterial hypertension of the European Society of Hypertension (ESH) and of the European Society of Cardiology (ESC). J Hypertens. 2013;31:1281-1357.

5. Bramlage P, Pittrow D, Wittchen HU, et al. Hypertension in overweight and obese primary care patients is highly prevalent and poorly controlled. Am J Hypertens. 2004;17:904-910.

6. Eguchi K, Pickering TG, Kario K. Why is blood pressure so hard to control in patients with type 2 diabetes? $J$ Cardiometab Syndr. 2007;2:114-118.

7. Stokes GS. Management of hypertension in the elderly patient. Clin Interv Aging. 2009;4:379-389.

8. Chobanian AV, Bakris GL, Black HR, et al. Seventh Report of the Joint National Committee on Prevention, Detection, Evaluation, and Treatment of High Blood Pressure. Hypertension. 2003;42:1206-1252.

9. Duprez D. Treatment of isolated systolic hypertension in the elderly. Expert Rev Cardiovasc Ther. 2012;10:1367-1373.

10. Kidambi S, Kotchen TA. Treatment of hypertension in obese patients. Am J Cardiovasc Drugs. 2013;13:163-175.

11. Mallat SG, Itani HS, Tanios BY. Current perspectives on combination therapy in the management of hypertension. Integr Blood Press Control. 2013;6:69-78.

12. Chiang CE, Wang TD, Li YH, et al. 2010 guidelines of the Taiwan Society of Cardiology for the management of hypertension. J Formos Med Assoc. 2010;109:740-773.

13. Chung N, Baek S, Chen MF, et al. Expert recommendations on the challenges of hypertension in Asia. Int J Clin Pract. 2008;62: 1306-1312.

14. Fujita T, Wu Z, Park J-B, Chen M-F. Briefings on JHS, CHS, KHS and THS guidelines and their difference from JNC VII and ESC/ESH. Int J Clin Pract. 2006;60:3-6.

15. Sison J, Assaad-Khalil SH, Najem R, et al. Real-world clinical experience of amlodipine/valsartan and amlodipine/valsartan/ hydrochlorothiazide in hypertension: the EXCITE study. Curr Med Res Opin. 2014;30:1937-1945.

16. Pistrosch F, Natali A, Hanefeld M. Is hyperglycemia a cardiovascular risk factor? Diabetes Care. 2011;34 Suppl 2:S128-S131.

17. Stearne MR, Palmer SL, Hammersley MS, et al. Tight blood pressure control and risk of macrovascular and microvascular complications in type 2 diabetes: UKPDS 38. UK Prospective Diabetes Study Group. BMJ. 1998;317:703-713.

18. Singer GM, Setaro JF. Secondary hypertension: obesity and the metabolic syndrome. J Clin Hypertens (Greenwich). 2008;10:567-574.

19. Landsberg L, Aronne LJ, Beilin LJ, et al. Obesity-related hypertension: pathogenesis, cardiovascular risk, and treatment - a position paper of the The Obesity Society and The American Society of Hypertension. Obesity (Silver Spring). 2013;21:8-24.

20. Chobanian AV, Bakris GL, Black HR, et al. The Seventh Report of the Joint National Committee on Prevention,Detection, Evaluation, and Treatment of High Blood Pressure: the JNC 7 report. JAMA. 2003;289: 2560-2572.

21. Weber MA, Schiffrin EL, White WB, et al. Clinical practice guidelines for the management of hypertension in the community: a statement by the American Society of Hypertension and the International Society of Hypertension. J Clin Hypertens (Greenwich). 2014;16:14-26.

22. Izzo JL Jr, Levy D, Black HR. Clinical Advisory Statement. Importance of systolic blood pressure in older Americans. Hypertension. 2000;35:1021-1024.

23. Calhoun DA, Lacourciere Y, Crikelair N, Jia Y, Glazer RD. Effects of demographics on the antihypertensive efficacy of triple therapy with amlodipine, valsartan, and hydrochlorothiazide for moderate to severe hypertension. Curr Med Res Opin. 2013;29:901-910.

24. Smith TR, Philipp T, Vaisse B, et al. Amlodipine and valsartan combined and as monotherapy in stage 2, elderly, and black hypertensive patients: subgroup analyses of 2 randomized, placebo-controlled studies. $J$ Clin Hypertens (Greenwich). 2007;9:355-364. 
25. Flack JM, Calhoun DA, Satlin L, Barbier M, Hilkert R, Brunel P. Efficacy and safety of initial combination therapy with amlodipine/ valsartan compared with amlodipine monotherapy in black patients with stage 2 hypertension: the EX-STAND study. J Hum Hypertens. 2009;23:479-489.

26. Allemann Y, Fraile B, Lambert M, Barbier M, Ferber P, Izzo JL Jr. Efficacy of the combination of amlodipine and valsartan in patients with hypertension uncontrolled with previous monotherapy: the Exforge in Failure after Single Therapy (EX-FAST) study. J Clin Hypertens (Greenwich). 2008;10:185-194.

27. Destro M, Luckow A, Samson M, Kandra A, Brunel P. Efficacy and safety of amlodipine/valsartan compared with amlodipine monotherapy in patients with stage 2 hypertension: a randomized, double-blind, multicenter study: the EX-EFFeCTS Study. J Am Soc Hypertens. 2008;2:294-302.

28. Calhoun DA, Crikelair NA, Yen J, Glazer RD. Amlodipine/valsartan/ hydrochlorothiazide triple combination therapy in moderate/severe hypertension: secondary analyses evaluating efficacy and safety. Adv Ther. 2009;26:1012-1023.
29. Poldermans D, Glazes R, Kargiannis S, et al. Tolerability and blood pressure-lowering efficacy of the combination of amlodipine plus valsartan compared with lisinopril plus hydrochlorothiazide in adult patients with stage 2 hypertension. Clin Ther. 2007;29:279-289.

30. Eckert S, Freytag SB, Muller A, Klebs SH. Meta-analysis of three observational studies of amlodipine/valsartan in hypertensive patients with additional risk factors. Blood Press. 2013;22 Suppl 1:11-21.

31. Kizilirmak P, Berktas M, Yalcin MR, Boyaci B. Efficacy and safety of valsartan and amlodipine single-pill combination in hypertensive patients (PEAK study). Turk Kardiyol Dern Ars. 2013;41: 406-417.

32. Hu D, Liu L, Li W. Efficacy and safety of valsartan/amlodipine singlepill Combination in 11,422 Chinese patients with hypertension: an observational study. Adv Ther. 2014;31:762-775.

33. Dusing R. Optimizing blood pressure control through the use of fixed combinations. Vasc Health Risk Manag. 2010;6:321-325.
Vascular Health and Risk Management

\section{Publish your work in this journal}

Vascular Health and Risk Management is an international, peerreviewed journal of therapeutics and risk management, focusing on concise rapid reporting of clinical studies on the processes involved in the maintenance of vascular health; the monitoring, prevention and treatment of vascular disease and its sequelae; and the involvement of

\section{Dovepress}

metabolic disorders, particularly diabetes. This journal is indexed on PubMed Central and MedLine. The manuscript management system is completely online and includes a very quick and fair peer-review system, which is all easy to use. Visit http://www.dovepress.com/ testimonials.php to read real quotes from published authors. 